\title{
PEMANFAATAN APLIKASI WHATSAPP PADA PELATIHAN KERAJINAN KAIN FLANEL DALAM PEMBERDAYAAN MASYARAKAT DI BENING SAGULING FOUNDATION
}

\author{
Mohamad Iqsan Hudri ${ }^{1}$, Sri Nurhayati ${ }^{2}$ \\ 1,2 Program Studi Pendidikan Masyarakat IKIP Siliwangi, Cimahi, Jawa Barat, Indonesia \\ ${ }^{1}$ iqsanhudri415@gmail.com, ${ }^{2}$ shrie33@yahoomail.com
}

Received: Juli, 2020; Accepted: September, 2020

\begin{abstract}
Community Empowerment is essentially a planned social change strategy aimed at addressing problems or meeting the needs of the community. In the process of empowerment, people get learning to be able to independently make efforts to improve their quality of life. The purpose of this research is (1) to know how to use the Whatsapp application in flannel fabric training in Community empowerment in Bening Saguling Foundation, (2) Knowing the process of using the Whatsapp application in flannel fabric training in Community empowerment in Bening Saguling Foundation, (3) Knowing the results of the use of Whatsapp application in the training of flannel fabric in community This research was conducted at Bening Saguling Village Babakan Cianjur, district of Cihampelas West Bandung Regency. The respondents in this study were the managers of Bening Saguling Foundation, tutors and three representatives of the citizens learned. The methods used in this study are descriptive and qualitative approaches that are facts based on the outcome of the field. The result of this research is expected to facilitate the tutor to provide material outside the lesson hours, and help residents learn the community around Bening Saguling in terms of science, life skills, and also in terms of economics. Their skills increased as well as the well-being of his life made easy.
\end{abstract}

Key words: Whatsapp Application, Training, Society empowerment

\begin{abstract}
Abstrak
Pemberdayaan masyarakat pada dasarnya merupakan strategi perubahan sosial secara terencana yang ditujukan untuk mengatasi masalah atau memenuhi kebutuhan masyarakat. Dalam proses pemberdayaan, masyarakat mendapatkan pembelajaran agar dapat secara mandiri melakukan upayaupaya perbaikan kualitas kehidupannya. Tujuan penelitian ini adalah (1) mengetahui cara pemanfaatan aplikasi Whatsapp pada pelatihan kain flannel dalam pemberdayaan masyarakat di Bening Saguling Foundation, (2) Mengetahui proses pemanfaatan aplikasi Whatsapp pada pelatihan kain flannel dalam pemberdayaan masyarakat di Bening Saguling Foundation, (3) Mengetahui hasil pemanfaatan aplikasi Whatsapp pada pelatihan kain flannel dalam pemberdayaan masyarakat di Bening Saguling Foundation. Penelitian ini dilakukan di Bening Saguling Desa Babakan Cianjur, Kecamatan Cihampelas Kabupaten Bandung Barat. Yang menjadi responden dalam penelitian ini adalah pengelola Bening Saguling Foundation, tutor dan tiga orang perwakilan dari warga belajar. Metode yang digunakan dalam penelitian ini adalah deskriptif dan pendekatan kualitatif yang merupakan fakta berdasarkan hasil lapangan. Hasil dari penelitian ini sesuai dengan yang diharapkan yaitu mempermudah tutor dalam memberikan materi diluar jam pelajaran, dan membantu warga belajar masyarakat di sekitar Bening Saguling dalam segi ilmu, life skill, dan juga dalam segi ekonominya. Keterampilan mereka menjadi meningkat juga kesejahteraan hidupnya pun menjadi dipermudah.
\end{abstract}

Kata kunci: Aplikasi Whatsapp, Pelatihan, Pemberdayaan Masyarakat.

How to Cite: Hudri, M.I. \& Nurhayati, S. (2020). Pemanfaatan Aplikasi Whatsapp Pada Pelatihan Kerajinan Kain Flanel Dalam Pemberdayaan Masyarakat Di Bening Saguling Foundation. Comm-Edu (Community Education Journal) 3 (3), 238-244. 


\section{PENDAHULUAN}

Pemberdayaan masyarakat pada dasarnya merupakan strategi perubahan sosial secara terencana yang ditujukan untuk mengatasi masalah atau memenuhi kebutuhan masyarakat. Dalam proses pemberdayaan, masyarakat mendapatkan pembelajaran agar dapat secara mandiri melakukan upaya-upaya perbaikan kualitas kehidupannya. Dengan demikian, proses tersebut harus dilaksanakan dengan adanya keterlibatan penuh masyarakat itu sendiri secara bertahap, terus-menerus, dan berkelanjutan. Payne (Nasdian, 2014, hal. 89) menyatakan bahwa pemberdayaan (empowerment) merupakan suatu proses yang ditujukan untuk membantu masyarakat memperoleh daya (kuasa) untuk mengambil keputusan dan menentukan tindakan yang akan ia lakukan, termasuk mengurangi efek hambatan pribadi dan sosial dalam melakukan tindakan. Suatu pemberdayaan tentunya memiliki tujuan yang akan dicapai. (Ife, 2008) menjelaskan bahwa "pemberdayaan bertujuan meningkatkan keberdayaan dari mereka yang dirugikan (the disadvantaged)".

Dalam era industri dan globalisasi sekarang ini tentunya teknologi sangat berkembang pesat. Dan sekarang ini kita sudah memasuki Industri 4.0 yang menjadi tantangan dalam perkembangan di Indonesia terutama dalam sistem ekonominya. Misalnya dijelaskan dalam artikel (Warta Ekonomi Online, 2019) industri 4.0 menjadi tantangan dalam setiap negara, dimana di Indonesia sendiri memicu hal positif untuk merevitalisasi industri nasional secara kesuluruhan terutama di bidang ekonomi misalnya, memberdayakan usaha mikro, kecil dan menengah melalui teknologi dengan fasilitasi platform e-commerce, kemudian memajukan jaringan internet untuk mendukung pengembangan infrastuktur digital.

Mengamati hal ini menjadi tantangan untuk salah satu Yayasan yang berdiri di Kabupaten Bandung Barat dalam memberantas permasalahan yang ada dimasyarakat. Yayasan Bening Saguling Foundation adalah lembaga swadaya masyarakat (LSM) yang berada dilingkungan padat penduduk, bertempat di Kampung Babakan Cianjur RT 08/04 Desa Cihampelas Kabupaten Bandung Barat yang didirikan tahun 2014 oleh bapak Indra Darmawan M.Pd. Berawal dari keprihatinan karena kerusakan lingkungan di Waduk Saguling yang diakibatkan adanya tumpukan sampah dan gulma eceng gondok yang bukan saja berdampak pada pendangkalan waduk, namun berdampak pula terhadap kondisi sosial masyarakat di sekitar. Rasa peduli dengan kelestarian lingkungan dan secara sukarela memberikan pelayanan kepada masyarakat umum tanpa tujuan memperoleh keuntungan dari kegiatannya.

Desa Cihampelas termasuk desa yang minim sumber daya manusia (SDM). Umumnya masyarakat yang menempati wilayah seluas 469 hektar dan hanya lulusan SLTP dengan tingkat penghasilan yang rendah. Hal ini menjadi tantangan tersendiri dalam sosialisasi pemberdayaan perempuan melalui pelatihan kain flanel kepada masyarakat di wilayah Bening Saguling Foundation dengan harapan dapat memberikan sumbangan pada peningkatan SDM dan membantu peningkatan ekonomi masyarakat di lingkungan setempat juga memanfaatkan komunikasi digital guna meningkatkan kualitas dan juga mengembangkan era industri sekarang ini. Hal tersebut tidak hanya melibatkan aspek- aspek pendidikan normatif semata, melainkan juga menuntut kesadaran dan partisipasi masyarakat untuk mencapai tujuan- tujuan lembaga tersebut karena nanti masyarakat sendirilah yang akan menikmati hasil dari pelatihan yang diselenggarakan.

Upaya untuk meningkatkan kehidupan yang lebih layak dan sejahtera tidak hanya melalui suatu pendidikan formal, melainkan dapat juga dikembangkan melalui pendidikan nonformal yaitu belajar kecakapan hidup (Life Skill Education). Namun pokok persoalan bagaimana 
menempatkan masyarakat yang tidak memiliki kesempatan untuk berpendidikan tinggi dapat di berdayakan. Apalagi di era digital sekarang banyak sekali masyarakat yang tentunya memiliki handphone sebagai alat komunikasi juga transaksi dan membuat pelatihan ini memanfaatkan aplikasi yang tentunya banyak masyarakat yang memakainya, salah satunya whatsapp.

Pelatihan Kerajinan kain flanel adalah alternatif usaha yang sangat baik di kembangkan dalam upaya pemberdayaan perempuan kepada masyarakat berpendidikan dan berpenghasilan rendah, remaja putus sekolah atau masyarakat usia kerja yang masih menganggur serta ibu rumah tangga karena disamping memiliki nilai ekonomis juga diminati oleh berbagai kalangan dan teknik pembuatan yang mudah serta peralatan jahit yang sederhana. Kegiatan yang dilakukan dalam pelatihan kerajinan kain flanel adalah melalui pemaparan teori, peningkatan keterampilan melalui pelatihan kain flanel, dan peningkatan ekonomi melalui praktik berwirausaha dengan menjual produk-produk hasil kerajinan kain flanel yang telah dibuat dimana mengaitkan dengan era digital yang nantinya melakukan penjualan dan juga sebagai tempat sharing, pemaparan teori jarak jauh antara warga belajar dengan tutor pelatihannya melalui aplikasi Whatsaap sebagai medianya. Hal ini termasuk kedalam implementasi pelatihan yang merupakan salah satu langkah pengelolaan pelatihan dan merupakan inti untuk mencapai tujuan sebagaimana dijelaskan dalam buku (Kamil, 2012, hal. 17) mengimplementasikan pelatihan, tahap ini merupakan inti dari kegiatan pelatihan, yaitu proses interaksi edukatif antara sumber belajar dengan warga belajar dalam mencapai tujuan yang ditetapkan.

Maka melihat hal ini saya sangat tertarik untuk mengangkat penelitian di Yayasan Bening Saguling Foundation karena kondisi yang sangat dekat dengan masyarakat dan juga pastinya Yayasan ini sangat memfasilitasi juga memecahkan permasalahan yang ada dilingkungan sekitar. Maka dari itu peneliti mengangkat judul "Pemanfaatan Aplikasi Whatsapp Pada Pelatihan Kerajinan Kain Flanel Dalam Pemberdayaan Masyarakat Di Bening Saguling Foundation".

\section{LANDASAN TEORI}

Teori Pelatihan

Pelatihan adalah salah satu cara untuk meningkatkan kualitas diri dan dilakukan dengan waktu yang singkat dengan mengutamakan keterampilan. Sebagaimana dijelaskan dalam buku (Kamil, 2012) dan diperkuat dalam intruksi Presiden No. 15 tahun 1974 bahwa Pelatihan adalah bagian pendidikan yang menyangkut proses belajar dalam memperoleh dan untuk meningkatkan keterampilan diluar sistem yang berlaku, dalam waktu yang relatif singkat, dan menggunakan metode yang lebih mengutamakan praktik daripada teori. Pelatihan memiliki tujuan untuk meningkatkan life skill guna mengembangkan potensi yang dimiliki agar bisa bekerja lebih baik sesuai dengan bidangnya. Sesuai yang dikemukakan oleh Michael J.Jucius dalam buku (Kamil, 2012, hal. 11) bahwa pelatihan bertujuan untuk mengembangkan bakat, keterampilan, dan kemampuan.

\section{Teori Pemberdayaan}

Pemberdayaan tentunya sangat berkaitan erat dengan masyarakat atau orang yang ada disekitar dalam setiap kegiatannya. (Novi Widiastuti, 2017) menjelaskan bahwa pemberdayaan adalah bagaimana menjadikan seseorang mampu berdiri sendiri dan bahkan membantu orang lain. 
Payne (Nasdian, 2014) menyatakan bahwa pemberdayaan (empowerment) merupakan suatu proses yang ditujukan untuk membantu masyarakat memperoleh daya (kuasa) untuk mengambil keputusan dan menentukan tindakan yang akan ia lakukan, termasuk mengurangi efek hambatan pribadi dan sosial dalam melakukan tindakan.

\section{METODE}

Dalam suatu penelitian, seorang peneliti disamping harus menetapkan pendekatan yang akan digunakan, ia juga harus memilih metode penelitian yang akan digunakan dengan mengacu kepada pendekatan penelitian yang telah ditetapkan sebelumnya. Terkait dengan itu, maka peneliti memilih pendekatan kualitatif dimana kata-kata sesuai disusun menjadi kalimat juga meneliti sesuai dengan data yang dikumpulkan, hal ini disampaikan dalam buku (Mulyana, 2004 ) pendekatan kualitatif yaitu penelitian tentang data yang dikumpulkan dan dinyatakan dalam bentuk kata-kata dan gambar, kata-kata disusun dalam kalimat. Misalnya kalimat hasil wawancara antara peneliti dengan informan.

Metode Penelitian ini juga menggunakan metode deskriptif yang berdasarkan fakta di lapangan, sesuai dengan dalam buku (Darmadi, 2014) yaitu pendekatan deskriptif dikatakan sebagai metode penelitian yang berusaha menggambarkan dan menginterpretasi objek sesuai dengan apa adanya.

Instrumen yang digunakan pada saat penilitan yaitu pedoman wawancara berupa lembar pertanyaan, pulpen dan handphone. Penelitian ini dilakukan di Bening Saguling Foundation Desa Babakan Cianjur, Kecamatan Cihampelas Kabupaten Bandung Barat. Yang menjadi responden dalam penelitian ini adalah pengelola Bening Saguling Foundation, tutor dan tiga orang perwakilan dari warga belajar masyarakat disekitar Bening Saguling Foundation yakni Ibu Rumah Tangga dalam usia produktif dan juga ingin mencukupi penghasilannya.

\section{HASIL DAN PEMBAHASAN}

\section{Hasil}

Dari hasil penelitian observasi dan wawancara peneliti dengan pengelola bening saguling sesuai dengan yang diharapkan pengelola, dimana dalam pelaksanaan pelatihan masyarakat mampu meningkatkan keterampilannya. Hal ini dilihat dari hasil karya kerajinan kain flanel yang berupa hanging door atau awan gantung untuk gantungan pintu, pensil dan boneka tangan yang dimana produk yang sudah dipilih dan layak nantinya akan dipasarkan melalui Aplikasi Whatsaap sebagai media jual beli online dimana peserta pelatihan ini melakukan foto produknya dari hasil kerajinan yang buat, lalu mereka mengunggah dan menawarkan kepada kontak yang ada di aplikasi whatsapp. Selain itu merekapun banyak melakukan sharing dengan tutor pelatihan diluar jam pelatihan, dan tak jarang juga untuk meminta materi baru berbentuk video dan gambar melalui Whatsapp.

Pelatihan kain flanel yang diadakan oleh lembaga Bening Saguling dua hari dalam satu minggu, tepatnya pada hari libur seperti Sabtu dan Minggu agar masyarakat lebih santai untuk mengikutinya dan waktunya pun lebih lama. Kegiatan ini dimulai dari pukul 13.00 hingga 15.00 waktu setempat yang tentunya ada beberapa tutor yang ahli dari pihak bening saguling fondation yang menjadi fasilitatornya. Namun dari hasil wawancara peneliti dengan tutor warga belajar lebih sering menanyakan atau mengulas kembali materi dan tata cara yang telah diajarkan melalui chat di aplikasi Whatsapp, sehingga tutor pun lebih sering mengirim video tutorial dan juga mengirim gambar tata cara dalam tahapan pembuatannya agar lebih jelas dan 
juga warga belajar bisa melihat secara berulang-ulang. Dalam hal ini tutor merasa tidak bisa selalu melayani setiap waktu secara langsung, sehingga tutorpun mengandalkan aplikasi Whatsapp sebagai media berbagi ilmunya.

Warga belajar dalam pelatihan ini adalah kaum perempuan yang bertempat tinggal di sekitar Yayasan Bening Saguling Foundation yang notabennya sebagai Ibu Rumah Tangga yang ingin meningkatkan penghasilan untuk keperluan hidupnya. Peneliti juga mewawancarai 3 warga belajar yang berinisial Il, Ir, dan Iy yang begitu antusias mengikuti pelatihan tersebut. selain menjadi ibu rumah tangga merekapun sudah terbiasa berpartisipasi dalam kegiatan Yayasan Bening Saguling, contohnya mereka tak jarang untuk menjadi pegawai harian dalam pembuatan kerajinan Eceng Gondok di yayasan tersebut. maka dari itu mereka ingin mengembangkan keterampilannya dan adanya kegiatan pelatihan sangat bermanfaat untuk mereka. Mereka memanfaatkan media digital melalui Aplikasi Whatsapp sebagai promosi dan tempat jual belinya dengan cara mengunggah gambar di statusnya dan chatting dengan para konsumennya sampai transaksi dan juga sebagai tempat konsultasi dengan tutornya. kemudian dari situ mereka mendapat penghasilan tambahan dari produk yang mereka jual. Mereka menjual berbagai jenis kerajinan dari kain flannel seperti boneka tangan, gantungan pintu, dan juga hiasan pensil. Peneliti melihat mereka juga lihai dalam menggunakan Aplikasi Whatsaap tersebut, karena aplikasi tersebut sudah biasa digunakan untuk komunikasi mereka sehari-hari jadi bukan hal yang sulit untuk mereka bisa berjualan dan mengobrol dalam aplikasi tersebut.

Pengelola sendiri menginginkan masyarakat untuk mengembangkan keahliannya dan juga mempunyai keterampilan guna meningkatkan efektifitas waktu dan juga menambah penghasilan ekonominya. Dengan adanya aplikasi Whatsapp masyarakat juga tentunya dipermudah dalam melakukan transaksi jual beli online serta komunikasi via jauh. Pengelola berharap masyarakat juga bisa makin berdaya untuk kedepannya karena tentunya kegiatan ini sangat memiliki dampak yang positif untuk masyarakat sendiri.

Dampak dari pelatihan kerajinan kain flanel terhadap warga belajarnya pun adalah bertambahnya ilmu dan keterampilan baru bagi warga belajar contohnya dari hasil wawancara terhadap mereka yang menjelaskan mereka mempunyai ilmu baru yang sebelumnya belum mereka pelajari yang dapat meningkatnya kesejahteraan hidup (subtitusi uang) serta menambah kreatifitas dan keterampilan untuk bekerja. Dari hal ini mereka pun menjelaskan bahwa melakukan beberapa transaksi terhadap konsumen yang memesan produk yang mereka buat sehingga pelatihan membantu finansial mereka, dalam satu kali pesanan warga belajar bisa mendapatkan minimal lima ribu hingga sepuluh ribu rupiah. Mereka juga sangat memanfaatkan media Aplikasi Whatsapp untuk promosi agar hasil produknya terjual laris. Sejauh ini kegiatan ini berjalan dengan baik dan juga mendapatkan income yang positif.

\section{Pembahasan}

Era industri 4.0 yang sedang berkembang saat ini sangat mempengaruhi kehidupan kita begitu juga untuk kedepannya. Salah satunya kita bisa menggunakan teknologi untuk bisa mengembangkan skill yang kita memiliki agar meningkatkan ekonomi kehidupan. (Warta Ekonomi Online, 2019) dalam artikelnya menjelaskan bahwa industri 4.0 menjadi tantangan dalam setiap negara, dimana di Indonesia sendiri memicu hal positif untuk merevitalisasi industri nasional secara kesuluruhan terutama di bidang ekonomi memberdayakan usaha mikro, kecil dan menengah melalui teknologi dengan fasilitasi platform e-commerce, kemudian memajukan jaringan internet untuk mendukung pengembangan infrastuktur digital. 
Adanya permasalahan di masyarakat khususnya dalam bidang ekonomi, tentunya sangat menjadi masalah serius bila tidak dibenahi. Yayasan Bening Saguling Foundation adalah Lembaga Swadaya Masyarakat (LSM) yang bergerak dalam bidang pemberdayaan dimana yayasan ini sangat dekat masyarakat juga mengikutsertakan masyarakat dalam setiap kegiatan. Pemberdayaan sangat penting untuk meningkatkan kualitas diri, sebagaimana dijelaskan dalam buku (Ife, 2008, hal. 662) bahwa "pemberdayaan bertujuan meningkatkan keberdayaan dari mereka yang ada dalam keadaan merugikan (the disadvantaged)".

Melalui pelatihan masyarakat bisa mengasah potensi dan juga meningkatkan kualitas diri (Kamil, 2012, hal. 11) bahwa pelatihan bertujuan untuk mengembangkan bakat, keterampilan, dan kemampuan. Dan hal ini sangat dirasakan oleh warga belajar yang mengikuti pelatihan dimana mereka bisa meningkatkan kualitas dirinya sesuai dengan keahlian mereka ditambah lagi dengan adanya tutor ahli untuk mendampingi dan melayani. Pengelola Yayasan Bening Saguling Foundation memberikan kesempatan kepada masyarakat sekitar untuk bisa mengembangkan life skill nya dan juga membuat mereka mempunyai penghasilan lebih, khususnya pada kaum perempuan kegiatan ini sangat bermanfaat dan mempunyai nilai ekonomis, dengan memanfaatkan handphone sebagai media jual beli dan tempat sharing ilmu juga yang nantinya produk yang layak akan dipasarkan melalui aplikasi Whatsapp dan juga sebagai tempat sharing warga belajar kepada tutornya. Tentunya hal ini juga termasuk kedalam implementasi pelatihan dan merupakan salah satu pengelolaan pelatihan yang dikutip dalam buku (Kamil, 2012, hal. 17) mengimplementasikan pelatihan, merupakan tahap inti dari kegiatan pelatihan, yaitu proses interaksi edukatif antara sumber belajar dengan warga belajar dalam mencapai tujuan yang ditetapkan.

Dalam kegunaannya Whatsaap memiliki koneksi 24 jam yang bisa tersambung dengan internet dan mudah digunakan oleh berbagai kalangan dimana kita bisa berbagi gambar, video, audio maupun dokumen dan masih ada beberapa kelebihan lain diantaranya:

1. Bisa bekerja pada semua jenis smartphone

2. Bisa mengirim lokasi

3. Mengatur status

\section{KESIMPULAN}

Cara pemanfaatan aplikasi Whatsapp pada pelatihan kain flannel dalam pemberdayaan masyarakat di Bening Saguling Foundation yaitu sebagai tempat sharing, konsultasi antara tutor dan warga belajarnya, dan juga sebagai media jual beli online dimana peserta menyebarkan gambar melakukan promosi dan chatting dengan pembeli dalam aplikasi Whatsapp tersebut.

Proses pada kegiatan ini berjalan dengan baik dan cukup efektif sehingga memudahkan tutor dalam memberikan materi jarak jauh dan diluar jam pembelajaran, dan juga memudahkan warga belajar dalam materi juga melakukan penjualan produknya.

Hasil dari pemanfaatan aplikasi Whatsapp dalam pelatihan ini sesuai dengan yang diharapkan yaitu mempermudah tutor dalam memberikan materi diluar jam pelajaran, dan membantu warga belajar masyarakat di sekitar Bening Saguling dalam segi ilmu, life skill, dan juga dalam 
244 Hudri \& Nurhayati, Pemanfaatan Aplikasi Whatsapp Pada Pelatihan Kerajinan Kain Flanel Dalam Pemberdayaan Masyarakat Di Bening Saguling Foundation

segi ekonominya. Keterampilan mereka menjadi meningkat juga kesejahteraan hidupnya pun menjadi dipermudah.

\section{DAFTAR PUSTAKA}

Darmadi, H. (2014). Metode Penelitian Pendidikan dan Sosial . Bandung : Alfabeta .

Ife, J. \&. (2008). Community development: alternatif pengembangan masyarakat di era globalisasi. Yogyakarta: Pustaka Pelajar .

Kamil, M. (2012). Model Pendidikan dan Pelatihan (Konsep dan Aplikasi). Bandung: Alfabeta

Mulyana, D. (2004 ). Metodologi Penelitian Kualitatif. Bandung : Remaja Rosda Karya .

Nasdian, F. (2014). Pengembangan Masyarakat. Jakarta: Yayasan Pustaka Obor Indonesia.

Widiastuti, N. Kartika, P. (2017). PENERAPAN MODEL KELOMPOK USAHA KREATIF ISLAMI (KUKIS) DALAM PEMBERDAYAAN PEREMPUAN BERBASIS PONDOK PESANTREN. empowerment, 23.

WE Online, J. (2019). Warta Ekonomi. Warta Ekonomi: wartaekonomi.co.id 